Publisher: LPPM STIE Muhammadiyah Bandung

P-ISSN: 2541-5255, E-ISSN: 2621-5306

Volume 2 Nomor 3, September - Desember 2018

\title{
PENGARUH KOMUNIKASI DAN KEPEMIMPINAN DALAM PENYELESAIAN KONFLIK
}

\author{
Dede Mustomi $^{1}$, Siswidiyanto ${ }^{2}$, Aprilia Puspasari $^{3}$ \\ ${ }^{1}$ Akademi Sekretari dan Manajemen UBSI Jakarta \\ e-mail: dede.ddo@bsi.ac.id \\ ${ }^{2}$ Akademi Manajemen dan Informatika UBSI Bekasi \\ e-mail: siswidiyanto.sid@bsi.ac.id \\ ${ }^{3}$ Akademi Sekretari dan Manajemen UBSI Jakarta \\ e-mail: aprilia.alp@bsi.ac.id
}

\begin{abstract}
Abstrak
Penelitian ini untuk melihat apakah ada pengaruh komunikasi dan kepemimpinan terhadap penyelesaian konflik. Komunikasi dan kepemimpinan yang merupakan bagian tidak terpisahkan dalam organisasi umumnya memiliki pengaruh kuat didalam organisasi atau bahkan tidak memiliki pengaruh sama sekali tergantung bagaimana mereka berkomunikasi dan menggunakan kepemimpinannya dalam mengelola organisasi. Konflik organisasi adalah ketidaksepakatan antara individu atau kelompok dalam organisasi, yang dapat memusatkan pada faktor mulai dari alokasi sumber daya dan pembagian tanggung jawab ke arah keseluruhan organisasi karyawan (Hossain, 2017). Struktur komunikasi organisasi didefinisikan sebagai sistem jalur di mana pesan mengalir atau sebagai pola interaksi di antara orang-orang yang membentuk organisasi (Nica dalam Hener, 2010). Pemimpin mempengaruhi orang lain melalui kemampuan mereka untuk memotivasi, menginformasikan, menginspirasi, teknis kompetensi, berkomunikasi secara efektif, dan menyampaikan visi (Pierce \& Newstrom dalam Kaimenyi, 2014).

Penelitian ini menggunakan metode correlational research yang bertujuan untuk mendeteksi sejauh mana variabel-variabel pada suatu faktor berkaitan dengan variabel pada faktor lain berdasarkan koefisien korelasi. Populasi sebesar 115 diambil 53 orang untuk diambil sebagai sampel
\end{abstract}

Kata Kunci: Komunikasi, Kepemimpinan, konflik.

\begin{abstract}
This research is to see how communication and leadership influence on conflict resolution. Communication and leadership which are an integral part of the organization generally have a strong influence in the organization or even have no influence at all depending on how they communicate and use their leadership in managing the organization. Organizational conflict is disagreement between individuals or groups within the organization, which can focus on factors ranging from resource
\end{abstract}


allocation and division of responsibility towards the overall employee organization (Hossain, 2017). Organizational communication structure is defined as the pathway system in which messages flow or as a pattern of interaction between people who form organizations (Nica in Hener, 2010). Leaders influence others through their ability to motivate, inform, inspire, technical competence, communicate effectively, and convey a vision (Pierce \& Newstrom in Kaimenyi, 2014).

This study uses correlational research method which aims to detect the extent to which variables in a factor are related to variables in other factors based on correlation coefficients. The population of 115 was taken by 53 people to be taken as a sample

Keywords: Communication, Leadership, Conflict

\section{PENDAHULUAN}

Konflik telah ada sejak manusia pertama ada dibumi, begitu cerita yang sering kita dengar, dari konflik besar antar negara sampai konflik didalam rumah tangga. Bila dua negara terjadi persilihan maka ada dua jalan yang bisa ditempuh kedua negara tersebut, yang pertama melalui jalan damai atau negosisasi dan yang kedua melalui jalan perang, jalan perang diambil biasanya ketika negosiasi buntu dan kedua belah pihak sudah merasa terancam karena menyangkut kedaulatan masingmasing pihak.

Konflik pun bisa terjadi di organisasi yang kecil seperti rumah tangga. Ketika dua pihak suami dan istri sering terjadi cekcok dan pertengkaran maka kemungkinan besar berpisah adalah jalan yang akan mereka ambil.

Perbedaan pendapat dan pertengkaran fisik adalah awal terjadinya konflik. Ketika percikan konflik sudah mulai terlihat maka harus segera dipadamkan, karena bila tidak, konflik akan membesar dan akan lebih sulit diatasi. Sejarah mencatat, indonesia pernah melewati berbagai konflik yang hampir memecah belah hidup berbangsa dan bernegara, seperti konflik antar etnis di sampit ataupun konflik berbau agama di ambon, konflik mungkin dimulai dari hal-hal sepele, tapi karena tidak ditangani dengan baik dan cepat maka konflik tersebut semakin membesar dan akhirnya lebih sulit diatasi, sehingga banyak memakan korban jiwa dan harta sesama anak bangsa.

Artikel ini fokus membahas konflik yang terjadi di perusahaan. Perusahaan yang merupakan sebuah organisasi dimana didalamanya hidup dan berinteraksi berbagai macam tipe manusia dan berbagai macam hak dan kewajiban. Gesekan satu sama lain adalah suatu hal yang biasa didalam perusahaan. Persaingan antar individu, persaingan antar divisi dan persaingan antar manajer selalu mewarnai kehidupan sebuah perusahaan. Tinggal bagaimana manajemen perusahaan mengelola kehidupan antar anggotanya agar sedapatnya tidak terjadi konflik, kalaupun konflik terjadi, maka bagaimana manajemen perusahaan cepat memadamkannya agar konflik tidak semakin melebar yang pada akhirnya akan mengganggu kinerja organisasi.

\section{TINJAUAN PUSTAKA}

Konflik memiliki pengaruh signifikan di tempat kerja yang dapat merusak lingkungan organisasi secara keseluruhan dan kinerja karyawan (Hossain, 2017). Definisi dasar dari konflik organisasi adalah ketidaksepakatan antara individu atau kelompok dalam organisasi, yang dapat memusatkan pada faktor mulai dari alokasi sumber daya dan pembagian tanggung jawab ke arah keseluruhan organisasi karyawan (Hossain, 2017). 
Selama organisasi terus menggunakan tim kerja, konflik tidak dapat dihindari karena ini merupakan aspek tim kerja yang tak terhindarkan. Konflik adalah hasil dari perilaku. Ini adalah bagian integral dari kehidupan manusia. Kapan ada interaksi ada konflik. Konflik berarti ekspresi permusuhan, sikap negatif, antagonisme, agresi, persaingan, dan kesalahpahaman. Ini juga terkait dengan situasi yang melibatkan minat yang bertentangan antara dua kelompok yang berseberangan. Ini dapat didefinisikan sebagai perselisihan antara dua atau lebih individu atau kelompok dengan masing-masing individu atau kelompok yang mencoba untuk mendapatkan penerimaan pandangannya atas orang lain (Thakore, 2013).

Konflik dalam kondisi tertentu dianggap berguna dan dapat diterima di dalam organisasi (Chaundry \& Asif, 2015). Konflik dapat mendukung organisasi dalam bergerak menuju pertumbuhan, meskipun, generalisasi seperti itu menggambarkannya sebagai faktor yang bermanfaat secara alami bagi organisasi. Telah dinyatakan lebih lanjut bahwa aspek disfungsional dari konflik cenderung memiliki efek yang lebih mendalam pada kelompok dan tim di tempat kerja dibandingkan dengan aspek fungsional (Chaundry \& Asif, 2015).

Konflik yang terjadi dalam organisasi dapat dikurangi melalui definisi pekerjaan yang memadai, spesifikasi terperinci hubungan antar posisi, pemilihan orang secara hati-hati untuk mengisi posisi, dan pelatihan menyeluruh dari orang-orang begitu mereka telah ditugaskan (Litterer dalam Chaundry \& Asif, 2015).

Peran komunikasi dan peran pimpinan diharapkan menjadi ujung tombak didalam meminimalisir terjadinya konflik didalam perusahaan. Kedua variabel itu yang akan dibahas didalam artikel ini.

\section{Penelitian terdahulu}

Penelitian ini merujuk kepada penelitian yang dilakukan sebelumnya oleh Ndulue dan Ekechukwu (2016) yang berjudul Impact of Conflict Management on Employees Performance: A Study of Nigerian Breweries Plc, Iganmu, Lagos State, Nigeria. Diterbitkan oleh European Journal of Business and Management. Ndulue dan Ekechukwu (2016) dalam penelitiannya yang menggunakan metode survei menyimpulkan ada hubungan yang signifikan antara manajemen konflik (tawarmenawar, kompromi dan memaksa) terhadap kinerja karyawan. Ini menunjukkan bahwa pendekatan manajemen konflik seperti tawar-menawar, kompromi dan pemaksaan secara statistik berkontribusi terhadap peningkatan semangat karyawan di Nigeria Breweries Plc. Artinya, melalui pengelolaan konflik, Nigeria Breweries Plc berhasil dalam meningkatkan kinerja karyawan.

Perbedaan penelitian Ndulue dan Ekechukwu (2016) dengan penelitian saya terletak pada variabel yang digunakan. Ndulue dan Ekechukwu (2016) menggunakan variabel bebas yakni bargaining issue, compromising dan forcing employees, sedangkan variabel terikatnya employees performance. Penelitian saya variabel bebasnya terdiri dari komunikasi dan kepemimpinan, sedangkan variabel terikatnya konflik di perusahaan.

Struktur komunikasi organisasi didefinisikan sebagai sistem jalur di mana pesan mengalir atau sebagai pola interaksi di antara orangorang yang membentuk organisasi (Nica dalam Hener, 2010). Komunikasi penting dalam menyelesaikan konflik organisasi karena dapat meningkat pemahaman dan mengurangi risiko salah dalam membuat kesimpulan (Hener, 2010). Ada banyak jenis dan bentuk komunikasi dalam organisasi. Dua dari yang paling penting adalah komunikasi formal dan informal, terutama untuk lembaga publik, di mana tingkat formalitas (baik 
oleh kebutuhan atau tradisi) lebih tinggi daripada di banyak jenis organisasi lainnya (Hener, 2010). Komunikasi formal adalah jenis komunikasi yang mengirimkan informasi melalui saluran yang ditunjuk secara resmi di antara berbagai posisi organisasi (Nica dalam Hener, 2010). Komunikasi informal mengandung interaksi yang tidak ada tempat di dalam saluran komunikasi yang resmi, hal ini perlu menciptakan iklim yang santai dan nyaman dan mengatasi masalah yang tidak dapat diakses oleh komunikasi formal, sehingga membantu berfungsinya organisasi (Hener, 2010).

Pemimpin mempengaruhi orang lain melalui kemampuan mereka untuk memotivasi, menginformasikan, menginspirasi, teknis kompetensi, berkomunikasi secara efektif, dan menyampaikan visi (Pierce \& Newstrom dalam Kaimenyi, 2014). Seorang pemimpin minimal menggunakan $25 \%$ dari waktunya untuk menghadapi dan memanajemeni konflik (Wirawan dalam Rozalina, 2013).

Transformasi kepemimpinan selalu terbuka akan potensi pemahaman yang lain yang lebih mendalam (Bagianto, Agus, and Yuniati Yuniati, 2017).

Konflik adalah bagian tak terpisahkan dari kehidupan berorganisasi, tapi apakah konflik ini akan menjadi konflik fungsional atau konflik disfungsional yang bisa memutuskan tingkat kinerja suatu organisasi (Christopher \& Reddy, 2011). Ada berbagai jenis konflik di tempat kerja, seperti konflik antar individu, konflik individu dengan organisasi, organisasi dengan pihak ketiga (Blackard \& Gibson dalam Christopher \& Reddy, 2011).

Manajemen konflik sebagai "penggunaan teknik resolusi dan stimulasi untuk mencapai derajat konflik yang diinginkan (Robbins \& Judge dalam Mister, Rini dan Karwan, 2017). Beberapa strategi yang dapat dilakukan untuk mengelola konflik yang dialami individu antara lain dengan mengelola: a) perilaku dari pelaku maupun pihak luar dalam mempengaruhi kepentingan (interests) dan melakukan interpretasi; b) hubungan pribadi (mengandung unsur-unsur konflik, pertentangan pendapat, atau perbedaan kepentingan), dan c) struktur organisasi (terdiri dari berbagai macam komponen yang berbeda dan saling memiliki ketergantungan dalam proses kerjasama untuk mencapai tujuan tertentu). (DeVitto dalam Mister, Rani \& Karwan, 2017).

Ada tiga model konseptual konflik : 1) Model tawar-menawar di mana kelompok-kelompok kepentingan bersaing untuk menjadi sumber daya yang unggul, 2) Model sistem yang mendefinisikan konflik di antara para pihak dalam hubungan lateral atau fungsional,dan khususnya masalah koordinasi, 3) Model birokrasi yang menggambarkan jenis konflik di antara atasan dan bawahan atau sepanjang dimensi vertikal dalam organisasi hirarki (Pondy dalam Kaimenyi, 2014).

Penyebab konflik meliputi ketakutan akan kesediaan sumber daya, bentuk kecurangan, ketidaknyamanan, penyerangan, kelelahan, emosi karyawan, bentuk hubungan yang terjalin, tingkat pemahaman dan pengalaman masa lalu (Zalabak dalam Anwar, 2015). Pada umumnya perilaku buruk yang kerap terjadi disebuah perusahaan adalah memeras, suap, menggertak, menipu, ketidakjujuran, intimidasi, pelanggran privasi, pelecehan seksual, anacaman pencurian,diskriminasi, pemberian informasi yang salah. Perilaku yang buruk memerlukan campur tangan manajemen, untuk itu mengelola perilaku buruk karyawan berhubungan dengan kesigapan manajer untuk bertanggung jawab, bertindak, memecahkan dan memperbaiki masalah (Ivancevich dalam Anwar, 2015).

Dalam konflik vertikal, tampaknya individu di tingkat organisasi yang lebih rendah berusaha menghindari konflik dengan tingkat hierarkis yang lebih tinggi rendah. Ini terjadi karena hal-hal berikut 
alasan: 1), orang-orang di tingkat hierarki yang lebih tinggi, daripada yang lebih rendah, terlibat dalam kegiatan non-rutin dan pengembangan politik, di mana orientasi untuk tindakan kurang jelas dan peluang untuk ketidaksetujuan, lebih besar dan; 2), orang-orang di tingkat hierarki yang lebih tinggi, mungkin kurang fleksibel dalam sudut pandang mereka (Pondy dalam Thakore, 2013).

Konflik tugas dapat terjadi dalam skenario ketika anggota tim mendapatkan arahan berbeda dari departemen yang berbeda. Karyawan mungkin harus menghadapi instruksi dari atasan mereka dan kepala departemen lain yang mungkin tidak kompatibel. Dalam beberapa kasus, anggota tim memiliki pendapat berbeda tentang cara melakukan tugas yang dialokasikan. Sulit untuk mengidentifikasi sudut pandang mana yang paling sesuai dalam situasi tersebut karena konflik tugas dapat meningkat menjadi afektif karena masuknya emosi negatif (Chaundry \& Asif, 2015).

Mengacu pada uraian diatas, penelitian ini bertujuan untuk mengetahui; 1) peran komunikasi dalam mengatasi konflik di perusahaan, 2) peran kepemimpinan dalam mengatasi konflik di perusahaan.

\section{METODE PENELITIAN}

Metode penelitian yang digunakan adalah correlational research yang bertujuan untuk mendeteksi sejauh mana variasi-variasi pada suatu faktor berkaitan dengan variasi pada faktor lain berdasarkan koefisien korelasi.

Populasi yang digunakan adalah mahasiswa semester lima jurusan akutansi yang sudah bekerja diberbagai perusahaan. Perhitungan banyaknya sampel menggunakan batas toleransi kesalahan (margin error) $10 \%$ atau dengan tingkat kepercayaan (level of confidence) 90\%. Penentuan ukuran sampel minimal dengan menggunakan rumus Slovin (Umar, 2005).
Tabel 1

\section{Rumus Slovin}

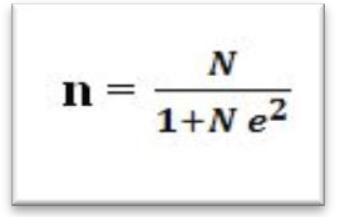

dengan: $\mathrm{n}=$ jumlah sampel

$\mathrm{N}=$ jumlah populasi

e = tingkat kesalahan (error) yang dapat ditoleransi pada penelitian

Teknik analisa data sampel responden untuk uji validitas dalam penelitian ini menggunakan Product Moment dari Pearson. Teknik analisa data sampel responden untuk uji reliabilitas dalam penelitian ini menggunakan teknik Alpha Cronbach's. Teknik analisa hipotesis dalam penelitian ini menggunakan teknik Multiple Regression, yang semuanya dengan bantuan program SPSS versi 22.

Variabel-variabel penelitian ini terdiri dari 2 variabel bebas dan satu variabel terikat. Variabelvariabel bebas pada penelitian ini meliputi: peran komunikasi (X1), peran kepemimpinan sedangkan variabel terikatnya yaitu penyelesaian konflik (Y).

Berikut adalah tabel pertanyaan-pertanyaan dalam survei:

Tabel 2

Pertanyaan Survei Komunikasi

\begin{tabular}{ll}
\hline No & \multicolumn{3}{c}{ Pertanyaan } \\
\hline 1 & Komunikasi yang terbuka merupakan ciri \\
& perusahaan anda \\
2 & Anda didorong untuk mengatakan apa yang anda \\
& pikirkan meskipun berbeda pendapat dengan \\
& atasan anda
\end{tabular}




\begin{tabular}{ll}
\hline 3 & Komunikasi antar karyawan berjalan kondusif \\
4 & Komunikasi antara karyawan dengan pimpinan \\
& berjalan kondusif \\
5 & $\begin{array}{l}\text { Komunikasi antar perusahaan dengan pihak luar } \\
\text { berjalan kondusif }\end{array}$ \\
\hline
\end{tabular}

Tabel 3

Pertanyaan Survei Kepemimpinan

\begin{tabular}{ll}
\hline No & \multicolumn{1}{c}{ Pertanyaan } \\
\hline 6 & $\begin{array}{l}\text { Pimpinan menerapkan reward dan punishment } \\
\text { kepada karyawan }\end{array}$ \\
7 & $\begin{array}{l}\text { Pimpinan membantu anda menyelesaikan } \\
\text { konflik yang dihadapi dalam pekerjaan }\end{array}$ \\
8 & $\begin{array}{l}\text { Pimpinan menciptakan lingkungan kerja yang } \\
\text { kondusif }\end{array}$ \\
9 & $\begin{array}{l}\text { Pimpinan mendorong anda untuk menghindari } \\
\text { konflik } \\
10\end{array}$ \\
\hline
\end{tabular}

\section{Tabel 4}

Pertanyaan Survei Penyelesaian Konflik

\begin{tabular}{ll}
\hline No & \multicolumn{1}{c}{ Pertanyaan } \\
\hline 1 & Manajemen menyelesaikan konflik dengan cepat \\
12 & Manajemen menyelesaikan konflik dengan adil \\
13 & Manajemen menyelesaikan konflik sesuai aturan \\
& perusahaan \\
14 & Manajemen menyelesaikan konflik dengan tuntas \\
15 & Manajemen menyelesaikan konflik dengan \\
& bermartabat \\
\hline
\end{tabular}

Dimana mahasiswa diminta menjawab survei tersebut dengan skala antara SS (sangat sesuai), $\mathrm{S}$ (sesuai), N (netral), TS (tidak sesuai) dan STS (sangat tidak sesuai).

\section{HASIL DAN PEMBAHASAN}

Data sampel kuesioner dari responden yang terkumpul sebanyak 53 responden dari total populasi sebesar 115. Berikut adalah tabel karakteristik demografik responden :
Tabel 5

\section{Data Demografik}

\begin{tabular}{llll}
\hline No & $\begin{array}{l}\text { Karakteristik } \\
\text { Demografik }\end{array}$ & Jumlah & Presentasi \\
\hline $\mathbf{1}$ & Gender & & \\
& Laki-Laki & 18 & $34 \%$ \\
& Perempuan & 35 & $66 \%$ \\
$\mathbf{2}$ & Usia & & \\
& $20 \quad$ tahun & & \\
& kebawah & - & - \\
& $20-25$ tahun & 41 & $77,4 \%$ \\
& $26-30$ tahun & 12 & $22,6 \%$ \\
& $31-40$ tahun & - & - \\
\end{tabular}

$\begin{array}{llll}3 & \text { Status } & & \\ & \text { Single } & 18 & 71,7 \% \\ & \text { Menikah } & 15 & 28,3 \% \\ & \text { Level Jabatan } & & \\ & \text { Direktur } & - & - \\ & \text { Manajer } & - & - \\ & \text { AsistenManajer } & - & - \\ & \text { Supervisor } & - & - \\ & \text { Staff } & 31 & 58,5 \% \\ & \text { Operator } & 22 & 41,5 \% \\ & & & \\ & \text { Lama Bekerja } & & \\ & \text { 0-5 tahun } & 53 & 100 \% \\ & \text { 6-10 tahun } & - & - \\ & & & \\ & & \end{array}$

Semua data sampel akan diolah dan dianalisa untuk uji validitas, uji reliabilitas dan uji hipotesis.

Uji validitas digunakan untuk mengukur sejauh mana ketepatan dan kecermatan suatu alat ukur dalam melakukan fungsi ukurnya. Untuk mengetahui apakah alat ukur menghasilkan data yang sesuai dengan tujuan yang sebenarnya maka dilakukan perhitungan korelasi antara skor item dengan skor total item yang dihitung menggunakan teknik korelasi 
product moment dari Pearson (Azwar, 2001). Uji validitas dikatakan valid jika $r$ hitung lebih besar $(>)$ dari $r$ tabel. Berikut adalah tabel hasil dari uji validitas dengan menggunakan Product Moment dari Pearson :

\section{Tabel 6}

Uji Validitas

\begin{tabular}{llll}
\hline $\begin{array}{l}\text { No } \\
\text { Item }\end{array}$ & r hitung & r tabel & Keterangan \\
\hline $\mathbf{1}$ & 0.425 & 0.270 & valid \\
$\mathbf{2}$ & 0.167 & 0.270 & tidak valid \\
$\mathbf{3}$ & 0.261 & 0.270 & tidak valid \\
$\mathbf{4}$ & 0.273 & 0.270 & valid \\
$\mathbf{5}$ & 0.372 & 0.270 & valid \\
$\mathbf{6}$ & 0.497 & 0.270 & valid \\
$\mathbf{7}$ & 0.474 & 0.270 & valid \\
$\mathbf{8}$ & 0.394 & 0.270 & valid \\
$\mathbf{9}$ & 0.426 & 0.270 & valid \\
$\mathbf{1 0}$ & 0.398 & 0.270 & valid \\
$\mathbf{1 1}$ & 0.491 & 0.270 & valid \\
$\mathbf{1 2}$ & 0.287 & 0.270 & valid \\
$\mathbf{1 3}$ & 0.486 & 0.270 & valid \\
$\mathbf{1 4}$ & 0.454 & 0.270 & valid \\
$\mathbf{1 5}$ & 0.357 & 0.270 & valid \\
\hline
\end{tabular}

Dari tabel 3 dapat dilihat hasil uji validitas dari 15 item kuesioner dimana hasilnya nilai nilai $\mathrm{r}$ hitung lebih besar dari $r$ tabel dinyatakan valid kecuali untuk item 2 dan item 3.

Setelah uji validitas, langkah selanjutnya adalah uji reliabilitas. Uji reliabilitas dilakukan untuk mengukur konsistensi atau keterpercayaan hasil ukur, yang mengandung makna kecermatan pengukuran (Azwar, 2001). Uji reliabilitas dalam penelitian ini menggunakan teknik Alpha Cronbach's. Uji reliabilitas dikatakan reliabel jika alpha lebih besar (>) dari r tabel Berikut hasil uji reliabilitas :
Tabel 7

Uji Reliabilitas

\begin{tabular}{|c|c|c|c|}
\hline $\begin{array}{l}\text { Nilai } \\
\text { hitung }\end{array}$ & $\mathbf{r}$ & Nilai $r$ tabel & $\begin{array}{c}\text { Alpha } \\
\text { Cronbach's }\end{array}$ \\
\hline 0.597 & & 0.270 & Reliabel \\
\hline
\end{tabular}

Dari uji reliabilitas dapat dilihat nilai Alpha $=0.597 .>\mathrm{r}$ tabel $=0.270$ karena nilai alpha lebih besar dari $r$ tabel artinya item-item dalam kuesioner dapat dikatakan reliabel.

Setelah uji validitas dan uji reliabilitas maka langkah selanjutnya adalah menguji hipotesis pengaruh variabel komunikasi (X1) dan variabel kepemimpinan (X2) terhadap variabel penyelesaian konflik (Y). Data yang dikumpulkan dianalisis dengan menggunakan Multiple Regression dengan bantuan program SPSS versi 22.

Untuk mengetahui hasil hipotesis, akan dilakukan terlebih dahulu uji t. Uji t digunakan untuk mengetahui apakah variabel-variabel independen secara parsial berpengaruh positif terhadap variabel dependen. Dalam uji t jika nilai Sig $<0.05$ atau $\mathrm{t}$ hitung > dari t tabel maka artinya terdapat pengaruh secara parsial variabel $\mathrm{X}$ terhadap variabel $\mathrm{Y}$ (Priyatno, 2008). Tingkat kepercayaan $95 \%$ atau $\mathrm{a}=$ 0,05 .

\section{Uji hipotesis 1 :}

Dalam uji $\mathrm{t}$ diketahui nilai Sig untuk pengaruh X1 terhadap Y sebesar 0,912>0,05 artinya nilai Sig lebih besar dari 0,05 atau nilai t hitung 0,111 $<$ r tabel 2.006 artinya nilai t hitung lebih kecil dari t tabel maka dapat disimpulkan bahwa $\mathrm{H} 1$ ditolak yang berarti tidak terdapat pengaruh variabel X1 terhadap Y.

\section{Uji hipotesis 2 :}

Dalam uji $t$ diketahui nilai Sig untuk pengaruh X2 terhadap Y sebesar $0.836>0.05$ artinya nilai Sig lebih besar dari 0,05 atau nilai t hitung 0,208 $<2.006$ artinya nilai t hitung lebih kecil dari t tabel maka dapat disimpulkan bahwa $\mathrm{H} 2$ ditolak yang 
berarti tidak terdapat pengaruh variabel X2 terhadap Y.

Dalam uji hipotesis pertama dan kedua dapat ditarik kesimpulan bahwa tidak terdapat pengaruh peran komunikasi dan kepemimpinan terhadap penyelesaian konflik.

\section{SIMPULAN}

Berdasarkan hasil pembahasan yang telah diuraikan diatas, dapat ditarik kesimpulan semua data sampel telah melalui uji validitas dan reliabilitas. Dari lima belas item hanya dua yang tidak valid yakni item nomor dua dan nomor tiga. Sedangkan dalam uji reliabilitas semuanya reliabel. Dalam uji hipotesis pertama didapatkan hasil nilai $\mathrm{t}$ hitung lebih kecil dari nilai $r$ tabel yang artinya tidak terdapat pengaruh komunikasi terhadap penyelesaian konflik. Dalam uji hipotesis kedua didapat hasil nilai t hitung lebih kecil dari $\mathrm{r}$ tabel yang artinya tidak terdapat pengaruh kepemimpinan terhadap penyelesaian konflik.diketahui tidak terdapat pengaruh signifikan prean komunikasi dan peran kepemimpinan terhadap penyelesaian konflik

\section{SARAN}

Penelitian ini hanya terbatas dari sudut pandang mahasiswa yang kuliah sambil bekerja. Tentu masih banyak elemen dan variabel bahkan sampel yang perlu dikembangkan untuk mendapatkan hasil yang berbeda. Ada banyak sudut pandang dan latar belakang yang mempengaruhi sebuah pendapat akan sesuatu. Begitupun dalam penelitian, pandangan dari para sampel yang telah memberikan pandangannnya bisa jadi berbeda dengan pihak lain. Sekali lagi banyak hal yang mempengaruhi dalam sebuah survei. Penelitian masih jauh dari sempurna dan diharapkan aka nada penelitian penelitian lain tentang manajemen konflik sehingga bisa memberikan pemikiran-pemikiran baru bagaimana mengelola konflik.

\section{DAFTAR PUSTAKA}

Anwar, Choerul. (2015). Manajemen Konflik Untuk Menciptakan Komunikasi Yang Eefktif. Interaksi Jurnal Ilmu Komunikasi (Vol. 4). https://ejournal.undip.ac.id/index.php/interaksi /article/view/9758

Azwar, Saifuddin. (2001), Reliabilitas dan Validitas, Yogyakarta, Pustaka Pelajar.

Bagianto, Agus, and Yuniati Yuniati. "Pengaruh Kepemimpinan dan Motivasi Anak Asuh terhadap Kesejahteraan Sosial Anak Asuh di Panti Asuhan Kurnia Asih Bandung." Jurnal Ilmiah MEA (Manajemen, Ekonomi, \& Akuntansi) 1.1 (2017): 10-29.

Chaundhry, M Atif., \& Asif, Rehman. (2015). Organizational Conflict and Conflict Management: a synthesis of literature. Journal of Business and Management Research (Vol. 9).http://www.knowledgejournals.com/PDF/10 2.pdf

Christopher, Prabu \& Reddy, S Bhanu. (2011). Exploring Leadership Styles During Conflict Management in Cross Cultural Scenario with Special Reference to Transactional and Transformational Leadership Styles. International Journal of Business Management, Economics And Information Technology (Vol. http://www.serialsjournals.com/serialjournalm anager/pdf/1330066190.pdf

Han, J., \& Kamber, M. (2006). Data Mining: Concepts and Techniques. Soft Computing 
(Vol. 54). https://doi.org/10.1007/978-3-642-

19721-5

Hener, Gabriela. (2010). Communication and Conflict Management in Local Public Organizations. Transylvanian Review of Administrative Sciences (No. 30). http://rtsa.ro/tras/index.php/tras/article/view/1 $73 / 169$

Hossain, Zahid Md. (2017). The Impact of Organizational Conflict on Employees' Performance in Private Commercial Banks of Bangladesh. IOSR Journal of Business and Management (IOSR-JBM) (Vol. 19). http://iosrjournals.org/iosr-jbm/papers/Vol19issue10/Version-2/C1910021221.pdf

Kaimenyi, K Catherine. (2014). The Influence of Conflict Management Styles on Leadership Approaches within Small-scale Businesses in Kenya. IOSR Journal of Business and Management (IOSR-JBM) (Vol 16). http://www.iosrjournals.org/iosrjbm/papers/Vol16-issue9/Version1/H016915559.pdf

Mister, Nyoman; Rini, Riswanti; Karwan, H Dedi. (2017). Pengaruh Efektivitas Komunikasi Manajemen Konflik dan Komitmen Terhadap Disiplin Kerja Guru. Jurnal Manajemen Mutu Pendidikan FKIP Unila (Vol. 5) http://jurnal.fkip.unila.ac.id/index.php/JMMP/ article/view/14262

Muspawi, Mohamad. (2014). Manajemen Konflik (Upaya Penyelesaian Konflik dalam Organisasi). Journal Unja (Vol. 16). http://onlinejournal.unja.ac.id/index.php/humaniora/article/ view/2035/1381

Ndulue, I Theresa., \& Ekechukwu, C Henry. (2016). Impact of Conflict Management on Employees Performance: A Study of Nigerian Breweries Plc, Iganmu, Lagos State, Nigeria. European Journal of Business and Management (Vol. 8). http://www.iiste.org/Journals/index.php/EJBM /article/download/29466/30256

Priyatno dwi. (2008). Mandiri belajar SPSS. Jogjakarta. Mediakom.

Rozalina, Nurfani. (2013). Pengaruh Gaya Kepemimpinan dan Manajemen Konflik terhadap Kinerja Karyawan PT.Sinar Sosro Kantor Penjualan Wilayah (KPW) Jawa Timur. Jurnal Eksekutif (Vol 10). https://jurnal.ibmt.ac.id/index.php/jeksekutif/a rticle/view/41

Thakore, Digvijaysinh. (2013). Conflict and Conflict Management. IOSR Journal of Business and Management (IOSR-JBM) (Vol. 8). http://www.iosrjournals.org/iosrjbm/papers/Vol8-issue6/B0860716.pdf

Umar, Husen. (2005). Metode Penelitian Untuk Skripsi dan Tesis Bisnis. Jakarta. PT RajaGrafindo Persada. 